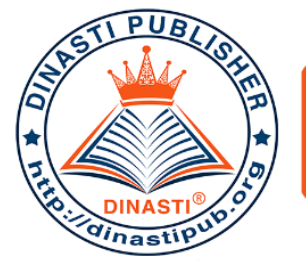

\title{
ANALYSIS OF THE EFFECTS OF PRODUCT QUALITY, PROMOTION \& LOCATION ON LOYALTY USING SATISFACTION AS THE MEDIATING VARIABLE AT LOTTEMART OF TAMAN SURYA JAKARTA
}

\author{
Dyah Ruth Wulandari ${ }^{1}$, Ngadino Surip ${ }^{2}$ \\ 1) Mercu Buana University, Jakarta, Indonesia \\ ${ }^{2)}$ Mercu Buana University, Jakarta, Indonesia
}

\begin{tabular}{|c|c|}
\hline $\begin{array}{c}\text { ARTICLE INFORMATION } \\
\text { Received: } 8^{\text {th }} \text { July } 2020 \\
\text { Revised: } 28^{\text {th }} \text { July } 2020 \\
\text { Issued: } 22^{\text {th }} \text { August } 2020 \\
\text { Corresponding author: Dyah Ruth } \\
\text { Wulandari } \\
\text { E-mail: } \\
\text { dyahruthw@gmail.com } \\
\text { dinosurip@gmail.com }\end{array}$ & $\begin{array}{l}\text { Abstract: This study aims to know and analyze the } \\
\text { influences of product quality, promotion and location } \\
\text { on the customer loyalty either directly or through the } \\
\text { customer satisfaction as the mediator variable and also } \\
\text { to know and analyze the influence of customer } \\
\text { satisfaction on the customer loyalty at hypermarket } \\
\text { Lottemart of Taman Surya. Data collection is } \\
\text { conducted through questionnaire. Sample used in this } \\
\text { study consists of } 400 \text { respondents of customers of } \\
\text { hypermarket Lottemart of Taman Surya Jakarta. The } \\
\text { sampling technique in this research uses non } \\
\text { probability sampling technique. The method of } \\
\text { analysis used is Partial Least Square (PLS) assisted } \\
\text { with SmartPLS application. The results of the research } \\
\text { reveal that quality product, promotion and location } \\
\text { have a positive and significant effect on customer } \\
\text { satisfaction. Product quality, promotion and customer } \\
\text { satisfaction have a positive and significant effect on } \\
\text { customer loyalty but location has no significant effect } \\
\text { on customer loyalty. } \\
\text { Keywords: Product Quality, Promotion, Location, } \\
\text { Satisfaction and Loyalty }\end{array}$ \\
\hline
\end{tabular}

\section{INTRODUCTION}

Global competition pattern that undergoes changes due shifts in customers' needs and pretensions as well as many changes in the global business environment must be able to be analyzed, therefore, business, including marketing strategy, needs to be changed in order to obtain opportunities and avoid the occurrence of threats. The retail industry is one of the largest and most diverse operations. According to the rating agency Fitch Ratings on the CNBC Indonesia website, major retailers in Indonesia such as supermarkets and hypermarkets were expected to experience growth slowdown in 2019 which would be an 
opportunity for the minimarket operator companies, due to changes in consumer choices that now prefer to shop in small quantities because of practicality and the closer distance between the minimarket and the buyer's house. Such dynamic changes add to the existing multidimensional retail problem, forcing to develop new strategies to overcome each of these challenges. The store-level marketing mix strategy is fundamental for retailers and plays an important role in increasing store traffic and revenue. Satisfying the customers' needs is important to drive them back to the store and maintain a profitable relationship with retailers because it is not easy to maintain customer loyalty in the midst of intense competition. Based on the above phenomenon, that the retail industry is overshadowed by the massive growth of minimarkets coupled with the expansion of e-commerce business, conventional retail businesses must set a strategy, considering business growth in the retail sector is still very promising, that means consumption in the retail sector is still very high.

The results of pre-study conducted by distributing questionnaires to 35 respondents randomly to find out the reason they shop at hypermarket Lottemart of Taman Surya. Identification of the source of profit in the complexity of existing factors (product quality, price, location, service, promotion, convenience, and atmosphere) with various possible combinations, it is obtained that the main reason customers make purchases at the store is consideration for product quality, promotion and location factors. This study aims to know and analyze the product quality, promotion and location affect the loyalty either directly or through customer satisfaction as the mediating variable and also the effect of customer satisfaction on customer loyalty of Lottemart of Taman Surya.

\section{Supporting Theories \\ Product Quality}

According to American Society for Quality Control, product quality is "the totality of features and characteristics of the products or services that depends on its ability to satisfy the stated or implied needs" (Kotler \& Keller, 2009). The seller has delivered quality when the product or service has met or exceeded the customer expectation. Quality reflects all dimensions of product offerings that produce benefits for customers (Tjiptono \& Chandra, 2017). According to Tjiptono quoted in the research journal by Hapzi, et.al (2017) in Ikhsani (2017), there are eight dimensions of product quality that are considered as attributes of an item evaluated by consumers, namely Product Performance, Product Features, Reliabilities, Conformance, Durability, Service abilities, Aesthetics and Fit \& Finish.

\section{Promotion}

According to Kotler and Armstrong (2018), "Promotion means activities that communicate the merits of the product and persuade target customers to buy it", with the dimensions of promotion namely advertising, sales promotion, public relations, personal selling and direct marketing, hereinafter used in this study.

\section{Location}

Retailers often point to three important factors in the retail success: location, location, location. It is important that retailers choose locations that are accessible to target markets in 
areas that are consistent with the retailer's position (Kotler \& Armstrong, 2018). Place marketing involves activities undertaken to create, maintain, or change attitudes or behaviors towards certain places (Kotler \& Armstrong, 2018). Factors in choosing a place or a physical location are, among other, access, visibility, traffic, parking lot, expansion, environment, competition, government regulations (Tjiptono \& Chandra, 2016).

\section{Satisfaction}

Satisfaction is someone's feeling of being happy or not happy generated from comparing the performance (or outcome) of products that are perceived to the expectations. If the performance is not as expected, the customer is not satisfied; If it is as expected, the customer is satisfied; If it exceeds the expectations, the customer is very satisfied or happy (Kotler \& Keller, 2013). According to Oliver (2010) in Fauzy (2019), customer satisfaction consists of three dimensions namely expectations, performance outcomes, subjective disconfirmation. A satisfied customer will remain loyal for longer periods of time, is willing to buy again when the company introduces new products and updates the old products, is talking good things about the company and its products to others, is not paying too much attention to competitors' brands, is also not being too sensitive to prices, is offering product or service ideas to the company, so, the service cost is lower than that of a new customer because the transaction can be routine (Kotler \& Keller, 2013).

\section{Loyalty}

Loyalty as "A deeply held commitment to buy or support products or services that are preferred in the future even though the influence of the situation and marketing efforts have the potential to cause customers to "switch" according to Oliver in Kotler \& Keller (2009). Marketing can be called the art of attracting and retaining profitable customers. Profitable customer is a person, a household, or a company that generates an income flow over time that exceeds the amount of the company's costs flow that can be tolerated to attract, sell and serve the customer (Kotler \& Keller, 2009). Dimension of loyalty according to Griffin (2005) in Mujianto (2017) are a repeat purchase, purchase across product and service line, referral and retention. Creating a strong and close relationship with customers is often the key to longterm marketing success (Kotler \& Keller, 2009). Customer loyalty is a reliable measure to predict sales growth and can be described based on a consistent purchase behavior (Stevan, 2018).

\section{LITERATURE REVIEW}

Theory of variables studied are both independent variable and dependent variable in order to find the dimensions of each variable. To prove the influence of independent variable on dependent variable, an analysis of dimensional relationship between the independent variable and the dependent variable is conducted. From the analysis of dimensional relationship, it is concluded that the independent variables affect the dependent variable, it is supported by the previous studies. The operational definition of each variable produces/finds 
indicators of the independent variable and the dependent variable. The indicators are used to create the research instruments (questionnaire).

According to Sugiono (2008), the operational definition is the determination of construct or trait to be studied so that it becomes a measurable variable. In this study, from a series of theories that have been discussed in the theoretical orientation, the operational definitions of each variable are as follows: Product quality is quality that reflects the quality of all dimensions of product offering that produces profit/benefit for customers. Promotion is a form of marketing communication that seeks to spread information, persuade and/or remind the target markets to a company and their products in order to be willing to accept, buy and be loyal to the products offered by the company concerned. Location is the place where the product is sold by a store that can be accessed, known/seen by eyes, so people can mill about without obstacles, it causes consumers to make spontaneous purchases and it has a large parking area. Satisfaction is a feeling of being satisfied felt by the customer after shopping at an offline retail store. Loyalty is a deeply held commitment to buy or support the favorite products back based on a positive attitude reflected in Repeat Purchase, Purchase Across Product \& Service Line, Referral and Retention in the future even though the influences of situation and marketing efforts have the potential to cause customers to switch.

In the context of product quality (goods and services) and customer satisfaction, a consensus has been reached that customer expectation plays an important role as a standard of comparison in evaluating both quality and satisfaction (Tjiptono \& Chandra, 2016). The results of studies conducted by previous researchers, among others Watanabe, Eluiza, et. al (2013) concluded that the product quality has a positive effect. Indrawati (2018) and Khoiruni (2018) concluded that product quality has a positive and significant effect. Aryamti (2019) concluded that product quality has a positive effect on customer satisfaction.

Marketing communication is a means by which companies try to inform, persuade and remind consumers directly or indirectly about the products and brands that are sold. In essence, marketing communication presents the "voice" of a company and its brand and is a means by which the company can make a dialog and build relationship with consumers (Kotler \& Keller, 2009). The company is successful in satisfying the customer needs and exceed their expectations economically and comfortably and through an effective communication (Kotler \& Keller, 2009). This marketing communication activity must be integrated to deliver consistent messages and achieve strategic positioning. This understanding will help them allocate communication funds more efficiently and design and implement the communication programs correctly (Kotler \& Keller, 2009). The results of research conducted by previous researchers, including Venkateswara (2015) concluded that promotion affects respondents' satisfaction. Muyi (2017) concluded that promotion has a positive and significant effect on customer satisfaction, Darma (2017) concluded that there is a positive and significant effect of promotion on customer satisfaction.

According to Kotler and Armstrong (2018), Place in the marketing mix includes the activities of companies that make products available to the target consumers. In relation to the heavy traffic and the high rental cost, retailers must decide the most profitable location for 
their outlets using traffic calculations, survey their consumers' spending habits and analyze the competitive locations. Retailers can assess the effectiveness of a particular store's sales by looking at four indicators namely the number of people who pass through it on a normal day, the percentage of people who enter the store, the percentage of people who make purchase and the average number per sale (Kotler \& Keller, 2009). The results of previous studies such as Sutarti (2014) and Fitri (2019) concluded that there is a significant effect from variable of location on customer satisfaction. Iqbal (2018) concluded that variable of location has a positive and significant effect on satisfaction.

Quality gives a special impetus for customers to build a long-term mutually beneficial relation with the company. This kind of emotional bonding allows the company to carefully understand the customers' specific expectations and needs. In turn, the company can increase the customer satisfaction by maximizing a pleasant customer experience so that customer satisfaction contributes to the creation of switching barriers, switching costs, and customer loyalty (Tjiptono \& Chandra, 2016). The results of studies by the previous researchers, among others: Alafityanto, (2017) that concluded that the product quality has a positive ad significant effect on customer loyalty. Amelia (2019) that concluded that product quality has a positive effect on customer loyalty.

The company's total promotional mix is also called its marketing communication mix consists of a specific mix of advertising, public relations, personal sales, sales promotions, and direct marketing tools that companies use to involve consumers, communicate the customer value convincingly, and build customer relationships (Kotler \& Armstrong, 2018). The results of studies conducted by previous researchers, among others: Muhammad (2017) that concluded that the promotion has a positive and significant effect on the dimension of loyalty. Ni Wayan Pradnya (2017) that concluded that promotion has a significant effect on customer loyalty. Khoirulloh (2018) that concluded that promotion has a positive and significant effect on customer loyalty.

Oliver (1999) in Tjiptono \& Chandra (2016) summarized the possibility (perspective) of the relationship between satisfaction and loyalty, that is satisfaction and loyalty are basically the same constructs, satisfaction is the core concept for loyalty, without satisfaction, loyalty will not exist. Satisfaction is just one component of loyalty. The existence of a superordinate concept, that is ultimate loyalty which includes "simple" satisfaction and loyalty. The existence of overlapping between satisfaction and loyalty, but with a relatively small percentage and satisfaction is the starting point of transition stages that culminates in separate loyalty rate.

Good customer relationship management creates customer satisfaction. In turn, satisfied customers remain loyal and talk well to others about the company and its products. Therefore, the goal of customer relationship management is to create not only customer satisfaction but also maintaining customer loyalty economically plausible (Kotler \& Armstrong, 2018). The results of studies by previous researchers, among others: Darma (2017), Fitri (2019) that concluded that the variable of customer satisfaction has a considerable influence on the variable of customer loyalty. Amelia (2019) that concluded that there is a positive influence of customer satisfaction on customer loyalty. 


\section{RESEARCH METHODS \\ Type of Research}

The research method which is used is quantitative research method. This research method is based on the philosophy of positivism used to examine specific populations/samples, the data collection uses research instruments, the data analysis is quantitative or statistical to test hypotheses that have been established by Sugiyono (2013) in Indrawati (2018)

\section{Research Variables}

In this study, the quality of product (X1), promotion (X2), location (X3) are independent variables. The mediating variable is satisfaction $(\mathrm{Y})$ whereas loyalty $(\mathrm{Z})$ is dependent variable. From the research variables, it is known that the dimensional analysis is obtained from theories conveyed by experts that further determine the indicators of each research variable which will later be the basis for determining questions/statements in the questionnaire. The research questions will become hypotheses if there is a framework.

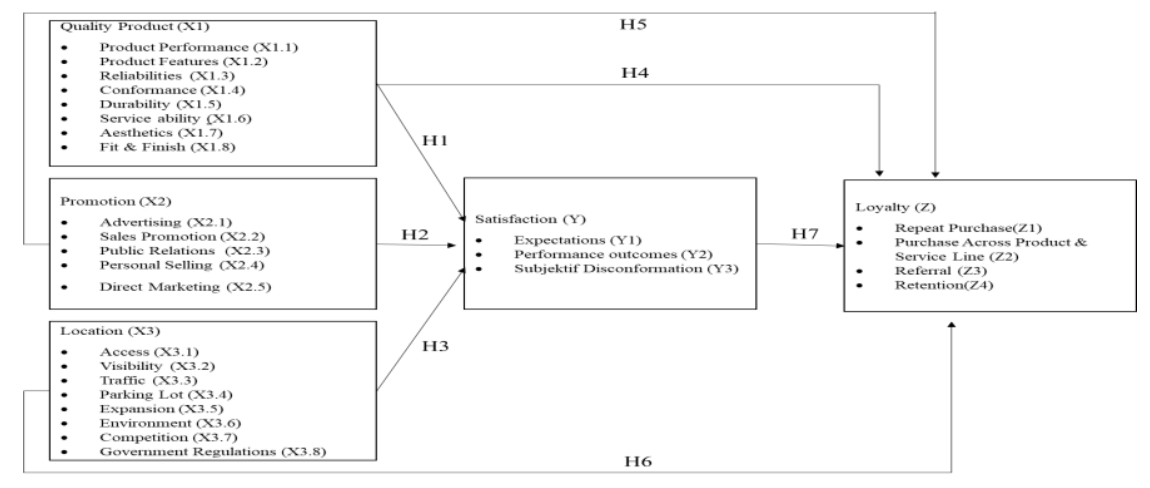

Figure 1. Framework

\section{Hypothesis}

From the above framework, the following hypotheses can be drawn:

H1: Products have a positive and significant effect on customer satisfaction

$\mathrm{H} 2$ : Promotion has a positive and significant effect on customer satisfaction

H3: Location of store has a positive effect on customer satisfaction

H4: Product quality has a positive and significant effect on customer loyalty

H5: Promotion has a positive and significant effect on customer satisfaction

H6: Location of store has a positive and significant effect on customer loyalty

H7: Customer satisfaction has a positive and significant effect on customer loyalty

\section{Population and Sample}

Population is a generalization area that consists of objects/subjects that have specific qualities and characteristics determined by researchers to be studied and to draw conclusions (Sugiyono, 2013). The population in this study was drawn from the number of active shopping customers registered as members of hypermarket Lottemart of Taman Surya in 
2018. The sample is part of the number and characteristics of the population (Sugiyono, 2013). In this study, the author used a sample of 400 respondents.

\section{Data Collection Technique}

The data collection in this study uses a questionnaire that is a data collection technique where respondents fill in questions or statements that after being filled out are then returned to the researcher (Sugiyono 2013). The measurement scale used is a Likert scale that will measure the agreement with a score of 1-5. Information regarding the division of scores and categories is as follows: Score $1=$ Strongly disagree (SD); Score $2=$ Disagree (D); Score 3 = Neutral (N); Score $4=$ Agree (A); Score $5=$ Strongly Agree (SA).

\section{Time and Place of Research}

In this study, the authors conducted the study in March 2020, the place of the research is at Hypermarket Lottemart of Taman Surya located at the Complex of Taman Surya V Block DD-1 JL. Satu Maret, Pegadungan Urban Village, Kalideres Sub-district, West Jakarta

\section{Data Analysis Technique}

Using partial least square (PLS) that the evaluation of the model conducted consists of two stages, namely the evaluation of the outer model and followed by the evaluation of the inner model:

a. Outer Model defines how each indicator relates to its latent variable. Tests carried out in the outer model:

1. Convergent Validity: Carried out by looking at the loading factor value for each construct indicator. A high loading factor value indicates that each construct indicator is converged at one point. The loading factor value will show how much the correlation between the indicator and the latent variable.

2. Average Variance Extracted (AVE): is one of the tests to see the validity of a construct.

3. Discriminant Validity: can be done by comparing the value of cross loading. The value of cross loading in the intended construct must be greater than the value of cross loading with other constructs.

4. Composite Reliability: used to test the reliability of a construct. The desired value for composite reliability is $>0.7$. Where values $>0.7$ are said to have a high reliability.

5. Cronbach Alpha: Reliability test reinforced with Cronbach alpha. The desired value for Cronbach alpha is > 0.7 (Sholihin \& Ratmono, 2013).

Inner Model or structural model analysis is carried out to ensure that the structural model constructed is accurate. Meanwhile, the tests carried out in the inner model is by looking at the coefficient of determination $\left(\mathrm{R}^{2}\right)$. The testing of $\mathrm{R}^{2}$ is a method to measure the level of Goodness of Fit (GOF) of a structural model. The value of $\mathrm{R}^{2}$ indicates what percentage of the variance of endogenous/criterion construct can be explained by the influence of hypothesized constructs (exogenous/predictor). The higher the value of $\mathrm{R}^{2}$ 
indicates a good model. The value of $\mathrm{R}^{2}$ is classified into three: $>0.75$ (substantial), $0.50-$ 0.75 (moderate) and $0.25-0.50$ (weak) (Sholihin \& Ratmono, 2013).

Q-square value $>0$ indicates that the model has a predictive relevance, so, on the contrary, if the Q-square value is < 0 , it indicates the model has less predictive relevance (Jogiyanto, (2009 in Indrawati (2018). The Q-square formula is: $\mathrm{Q} 2=1-\left(\left(1-\mathrm{R}_{1}{ }_{1}\right)\left(1-\mathrm{R}_{2}{ }_{2}\right)\right.$ .... (1- $\mathrm{R}_{\mathrm{p}}^{2}$ ) (1)To test the hypothesis, the statistical test " $t$ " with a significance level $\alpha=5 \%$ is conducted. If the value of $t$ arithmetic is $>1.96$, then the hypothesis is accepted and on the contrary, if $\mathrm{t}$ arithmetic is $<1.96$, then the hypothesis is rejected.

\section{Dimensional Analysis}

Dimensional analysis is used to know the strength of the relationship between the independent variable dimension and the dependent variable dimension, therefore, a correlation coefficient interval table is needed (Riadi, 2016 in Azisiah, 2018) that can be grouped as follows:

Table 1. Correlation Coefficient Interval

\begin{tabular}{|c|c|}
\hline Coefficient Interval & Level and Strength of Relationships \\
\hline $0.0-0.19$ & Very low or invalid relationship \\
\hline $0.2-0.39$ & Low \\
\hline $0.4-0.59$ & Strong enough \\
\hline $0.6-0.79$ & Strong \\
\hline $0.8-1.00$ & Very Strong \\
\hline
\end{tabular}

\section{FINDINGS AND DISCUSSION}

Table 2. Convergent Validity

\begin{tabular}{|c|c|c|c|c|c|}
\hline Questions & $\begin{array}{c}\text { Satisfaction } \\
(\mathbf{Y})\end{array}$ & $\begin{array}{c}\text { Location } \\
(\mathbf{X 3})\end{array}$ & $\begin{array}{c}\text { Loyalty } \\
(\mathbf{Z})\end{array}$ & $\begin{array}{c}\text { Product } \\
\text { Quality } \\
(\mathbf{X 1})\end{array}$ & $\begin{array}{c}\text { Promotion } \\
(\mathbf{X 2})\end{array}$ \\
\hline K01 & & & & 0.628 & \\
\hline K02 & & & & 0.701 & \\
\hline K03 & & & & 0.719 & \\
\hline K04 & & & & 0.604 & \\
\hline K08 & & & & 0.638 & \\
\hline K12 & & & & 0.689 & \\
\hline
\end{tabular}

\begin{tabular}{|c|c|c|c|c|c|}
\hline Questions & $\begin{array}{c}\text { Satisfaction } \\
(\mathbf{Y})\end{array}$ & $\begin{array}{c}\text { Location } \\
(\mathbf{X 3 )}\end{array}$ & $\begin{array}{c}\text { Loyalty } \\
(\mathbf{Z})\end{array}$ & $\begin{array}{c}\text { Product } \\
\text { Quality } \\
(\mathbf{X 1 )}\end{array}$ & $\begin{array}{c}\text { Promotion } \\
(\mathbf{X 2 )}\end{array}$ \\
\hline K13 & & & & 0.698 & \\
\hline K14 & & & & 0.645 & \\
\hline K15 & & & & 0.711 & \\
\hline K16 & & & & 0.784 & \\
\hline L22 & & 0.774 & & & \\
\hline L23 & & 0.804 & & & \\
\hline L24 & & 0.824 & & & \\
\hline L25 & & 0.781 & & & \\
\hline L26 & & 0.687 & & & \\
\hline L27 & & 0.775 & & & \\
\hline L28 & & 0.699 & & & \\
\hline L29 & & 0.694 & & & \\
\hline P17 & & & & & 0.690 \\
\hline P18 & & & & & 0.760 \\
\hline P19 & & & & & 0.712 \\
\hline P20 & & & & & 0.754 \\
\hline P21 & & & & & \\
\hline Y30 & 0.846 & & & & \\
\hline Y31 & 0.845 & & & & \\
\hline Y32 & 0.815 & & & & \\
\hline Z33 & & & 0.816 & & \\
\hline Z34 & & & 0.824 & & \\
\hline Z35 & & & 0.773 & & \\
\hline Z36 & & & 0.780 & & \\
\hline Z37 & & & 0.821 & & \\
\hline Z38 & & & 0.842 & & \\
\hline Z39 & & & 0.778 & & \\
\hline Z40 & & & 0.666 & & \\
\hline Z41 & & & 0.733 & & \\
\hline & & & & & \\
\hline
\end{tabular}


The table above can be interpreted that after invalid indicators are deleted, in the picture above, all indicators have a loading factor $>0.60$, that mean all indicators are valid indicators to measure the construct. There are several criteria for assessing reliability, including composite reliability, Cronbach's alpha and AVE as shown in the following table:

Table 3. Construct Reliability and Validity Table

\begin{tabular}{|l|c|c|c|c|}
\hline \multicolumn{1}{|c|}{ Variable } & Cronbach's Alpha & rho_A & Composite Reliability & Average Variance Extracted (AVE) \\
\hline Product Quality (X1) & 0.873 & 0.882 & 0.897 & 0.467 \\
\hline Promotion (X2) & 0.796 & 0.801 & 0.860 & 0.552 \\
\hline Location (X3) & 0.892 & 0.893 & 0.914 & 0.572 \\
\hline Satisfaction (Y) & 0.784 & 0.785 & 0.874 & 0.698 \\
\hline Loyalty (Z) & 0.920 & 0.925 & 0.934 & 0.613 \\
\hline
\end{tabular}

The table above shows that Cronbach's alpha of each construct is $>0.70$, composite reliability of each construct is $>0.70$ and average variance extracted (AVE) of each construct is $>0.50$ (except X1) that mean all constructs are reliable. Thus, the measurement items for each variable are declared reliable and can then be used in research.

\section{Relations Between Constructs}

Table 4. Path Coefficients Table

\begin{tabular}{|l|c|c|c|c|c|}
\hline \multicolumn{1}{|c|}{ Variable } & Original Sample (O) & Sample Mean (M) & Standard Deviation (STDEV) & T Statistics (O/STDEV) & P Values \\
\hline Product Quality (X1) --> Satisfaction (Y) & 0.162 & 0.170 & 0.053 & 3.087 \\
\hline Product Quality (X1) --> Loyalty (Z) & 0.316 & 0.311 & 0.061 & 0.002 \\
\hline Promotion (X2) --> Satisfaction (Y) & 0.153 & 0.153 & 0.069 & 0 \\
\hline Promotion (X2) --> Loyalty (Z) & 0.226 & 0.233 & 0.076 & 0.207 \\
\hline Location (X3) --> Satisfaction (Y) & 0.513 & 0.509 & 0.066 & 2.222 \\
\hline Location (X3) --> Loyalty (Z) & 0.064 & 0.068 & 0.057 & 0.027 \\
\hline Satisfaction (Y)--> Loyalty (Z) & 0.281 & 0.277 & 0.058 & 0.762 \\
\hline
\end{tabular}

The $t$ test is intended to test whether the independent variable partially has a significant effect on the dependent variable.

a. Hypothesis:

$\mathrm{H} 0$ : the variable $\mathrm{Y}$ has no significant effect on the variable $\mathrm{Z}$

$\mathrm{H} 1$ : the variable $\mathrm{Y}$ has a significant effect on the variable $\mathrm{Z}$

b. Basis for Decision Making

- If the probability (prob value) is $>0.05$ or $-\mathrm{t}$ table $<\mathrm{t}$ count $<\mathrm{t}$ table then $\mathrm{H} 0$ is not rejected

- If the probability (prob value) is $<0.05$ or $t$ count $<-t$ table or $t$ count $>t$ table then $\mathrm{H} 0$ is rejected ( $\mathrm{t}$ table for alpha $=0.05$ is 1.96 and $\mathrm{t}$ table for alpha $=0.10$ is 1.65 )

c. Decision:

1. Product Quality (X1) on Satisfaction (Y): In the table above, the value of $t$ stat $=3.087$ > 1.96, which means the variable of product quality (X1) has a positive and significant effect on the variable of satisfaction (Y).

2. Product Quality (X1) on Loyalty (Z): where the value of $t$ stat $=5.207>1.96$ which means the variable of product quality $(\mathrm{X} 1)$ has a positive and significant effect on the variable of loyalty (Z). 
3. Promotion (X2) on Satisfaction (Y): where the value of $t$ stat $=2.222>1.96$ which means the variable of promotion (X2) has a positive and significant effect on the variable of satisfaction $(\mathrm{Y})$.

4. Promotion (X2) on Satisfaction (Y): where the value of $t$ stat $=2.981>1.96$ which means the variable of promotion (X2) has a positive and significant effect on the variable of loyalty (Z).

5. Location (X3) on Satisfaction (Y): where the value of $t$ stat $=7.762>1.96$ which means the variable of location (X3) has a positive and significant effect on the variable of satisfaction (Y).

6. Location (X3) on Loyalty (Z): where X3 has no significant effect on Z, because the value of $\mathrm{t}=1.131<1.96$. In the table above, the value of $\mathrm{t}$ stat $=1.131<1.96$ so that $\mathrm{H} 0$ is accepted and $\mathrm{H} 1$ is rejected, which means that the variable of location (X3) has no significant effect on the variable of loyalty $(Z)$.

7. Satisfaction $(Y)$ on Loyalty $(Z)$ : where the value of $t$ stat $=4.834>1.96$ which means the variable of satisfaction $(Y)$ has a positive and significant effect on the variable of loyalty $(Z)$. Thus, the structural equation is:

$\mathrm{Y}=0.162 * \mathrm{X} 1+0.153 * \mathrm{X} 2+0.513 * \mathrm{X} 3+\mathrm{e}$

$\mathrm{Z}=0.316^{*} \mathrm{X} 1+0.226 * \mathrm{X} 2+0.064 * \mathrm{X} 3+0.281 * \mathrm{Y}+\mathrm{e}$

Table 5. Path Coefficient Table

\begin{tabular}{|l|c|c|}
\hline \multicolumn{1}{|c|}{ Variable } & Satisfaction (Y) & Loyalty (Z) \\
\hline Product Quality (X1) & 0.162 & 0.316 \\
\hline Promotion (X2) & 0.153 & 0.226 \\
\hline Location (X3) & 0.513 & 0.064 \\
\hline Satisfaction (Y) & & 0.281 \\
\hline
\end{tabular}

Table 6. R Square Data Table

\begin{tabular}{|l|c|c|}
\hline \multicolumn{1}{|c|}{ Variable } & R Square & R Square Adjusted \\
\hline Satisfaction $(\mathrm{Y})$ & 0.552 & 0.549 \\
\hline Loyalty $(\mathrm{Z})$ & 0.580 & 0.576 \\
\hline
\end{tabular}

The coefficient of determination ( $\mathrm{R}$ square adjusted) is used to show how much the influence of the influencing variables on the affected variables. Based on the above table, the value of $\mathrm{R}$ square adjusted of the equation $\mathrm{Y}=0.162 * \mathrm{X} 1+0.153 * \mathrm{X} 2+0.513 * \mathrm{X} 3+\mathrm{e}$ from the table above is 0.549 indicating that $54.9 \%$ of the variance $Y$ can be explained by changes in variables $X 1, X 2$ and $X 3$, whereas another $45.1 \%$ is caused by other factors outside the model. Based on the table above, the value of $\mathrm{R}$ square adjusted of the equation $\mathrm{Z}=$ $0.316 * \mathrm{X} 1+0.226 * \mathrm{X} 2+0.064 * \mathrm{X} 3+0.281 * \mathrm{Y}+\mathrm{e}$ from the table above is 0.576 indicating that $57.6 \%$ of the variance $\mathrm{Z}$ can be explained by changes in variables $\mathrm{X} 1, \mathrm{X} 2, \mathrm{X} 3$ and $\mathrm{Y}$, while another $42.4 \%$ is caused by other factors outside the model. The value of Q-square predictive relevance can be measured using the following method: $\mathrm{Q}=1-\left(1-\mathrm{R}^{2}\right.$ Customer Satisfaction) $\mathrm{x}\left(1-\mathrm{R}^{2}\right.$ Customer Loyalty)

$=1-(1-0.549) \times(1-0.576)$

$=1-0.1912$

$=0.8088$

The value of Q-square in this study is amounted to 0.8088 or $>0$ so, it can be said that the model has predictive relevance or indicates that the structural model designed to explain the 
customer satisfaction and the customer loyalty for the customers of Hypermarket Lottemart of Taman Surya is proved to be good and relevant.

Path Analysis

This is the basic model used to analyze the path in estimating the strength of a relationship - a causal relationship described in the path model. Path analysis can be used because it is presumed that there is a correlational relationship between independent variables, so there is a direct effect and an indirect effect on the dependent variable.

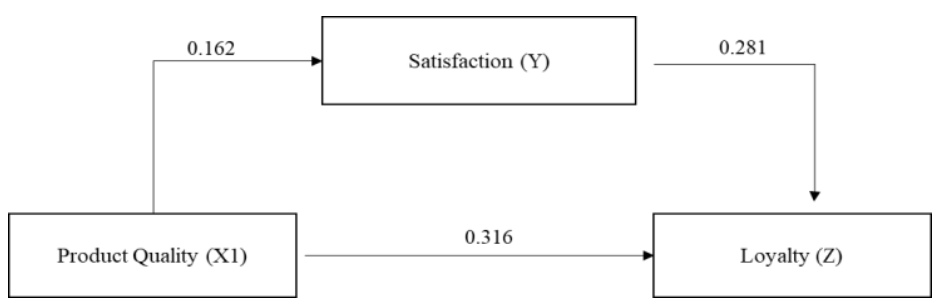

Figure 2. Product Quality Path Analysis Diagram

a. Direct effect

- Effect of Product Quality (X1) on Satisfaction (Y) $=0.162$

- Effect of Satisfaction (Y) on Loyalty $(\mathrm{Z}) \quad=0.281$

- Effect of Product Quality (X1) on Loyalty (Z) $\quad=0.316$

b. Indirect effect

Effect of Product Quality (X1) on Loyalty (Z) through Satisfaction (Y)

$=0.162 \times 0.281=0.046$

c. Total Effect

Loyalty $(Z)=$ Direct Effect + Indirect Effect

$=0.316+0.046=0.361$

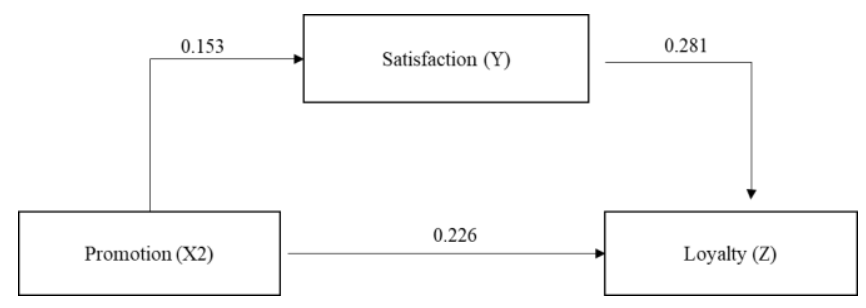

Figure 3. Promotion Variable Path Analysis Diagram

a. Direct effect

- Effect of Promotion (X2) on Satisfaction (Y) $\quad=0.153$

- Effect of Satisfaction (Y) on Loyalty $(\mathrm{Z}) \quad=0.281$

- Effect of Promotion (X2) on Loyalty $(\mathrm{Z}) \quad=0.226$

b. Indirect effect

Effect of Product Quality (X1) on Loyalty (Z) through Satisfaction (Y)

$=0.153 \times 0.281=0.043$

c. Total Effect 
Loyalty $(\mathrm{Z})=$ Direct Effect + Indirect Effect

$$
=0.226+0.043=0.270
$$

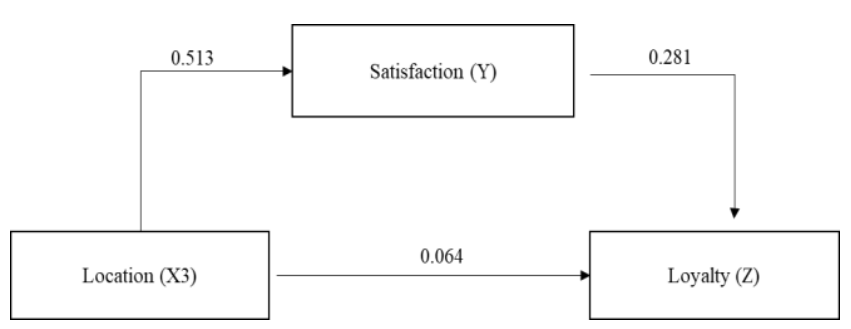

Figure 4. Location Variable Path Analysis Diagram

a. Direct effect

- Effect of Location (X3) on Satisfaction $(\mathrm{Y})=0.513$

- Effect of Satisfaction (Y) on Loyalty $(\mathrm{Z}) \quad=0.281$

- Effect of Location (X3) on Loyalty $(\mathrm{Z}) \quad=0.064$

b. Indirect effect

Effect of Product Quality (X1) on Loyalty (Z) through Satisfaction (Y)

$=0.513 \times 0.281=0.144$

c. Total Effect

Loyalty $(Z)=$ Direct Effect + Indirect Effect $=0.064+0.144=0.208$

Based on the calculation of the path analysis above, the total of indirect effects between the variables of product quality, promotion and location can be seen in the following table:

Table 7. Specific Indirect Effects

\begin{tabular}{|l|c|}
\hline \multicolumn{1}{|c|}{ Variable } & Specific Indirect Effects \\
\hline Product Quality (X1) --> Satisfaction (Y)--> Loyalty (Z) & 0.046 \\
\hline Promotion (X2) --> Satisfaction (Y)--> Loyalty (Z) & 0.043 \\
\hline Location (X3) --> Satisfaction (Y)--> Loyalty (Z) & 0.144 \\
\hline
\end{tabular}

From the table above, it can be explained that each variable, both variables of product quality, promotion and location has an indirect effect indicating a positive direction on customer loyalty through customer satisfaction.

The total direct effects can be seen in the following table:

Table 8. Total Effects

\begin{tabular}{|l|c|c|}
\hline \multicolumn{1}{|c|}{ Variable } & Satisfaction $(\mathbf{Y})$ & Loyalty $(\mathbf{Z})$ \\
\hline Product Quality (X1) & 0.162 & 0.316 \\
\hline Promotion (X2) & 0.153 & 0.270 \\
\hline Location (X3) & 0.513 & 0.208 \\
\hline Satisfaction (Y) & & 0.281 \\
\hline
\end{tabular}

Correlation Analysis Between Dimensions: 
Table 9. Pearson Dimensions Correlation of Product Quality Variables

\begin{tabular}{|c|c|c|c|c|c|c|c|c|c|c|c|c|c|c|c|}
\hline Variable & \multicolumn{2}{|c|}{ Dimension } & $\begin{array}{c}\text { Pearson } \\
\text { Correlation }\end{array}$ & $\begin{array}{c}\text { Expec } \\
\text { tation } \\
\text { (Y1) }\end{array}$ & $\begin{array}{c}\text { Perfor } \\
\text { mance } \\
\text { Outco } \\
\text { mes } \\
(\text { Y2) } \\
\end{array}$ & $\begin{array}{c}\text { Subjective } \\
\text { Disconfor } \\
\text { mation } \\
\text { (Y3) }\end{array}$ & $\begin{array}{c}\text { Repeat } \\
\text { Purchase } \\
\text { (Z1.1) }\end{array}$ & $\begin{array}{c}\text { Repeat } \\
\text { Purchase } \\
\text { (Z1.2) }\end{array}$ & \begin{tabular}{|c|} 
Purchase \\
Across \\
Product \\
and Service \\
Line (Z2.1) \\
\end{tabular} & $\begin{array}{c}\text { Purchase } \\
\text { Across } \\
\text { Product and } \\
\text { Service Line } \\
\text { (Z2.2) } \\
\end{array}$ & $\begin{array}{c}\text { Refferal } \\
(\text { Z3.1) }\end{array}$ & $\begin{array}{c}\text { Refferal } \\
(\mathbf{Z 3 . 2})\end{array}$ & $\begin{array}{c}\text { Refferal } \\
\text { (Z3.3) }\end{array}$ & $\begin{array}{c}\text { Retention } \\
\text { (Z4.1) }\end{array}$ & $\begin{array}{c}\text { Retention } \\
(\mathbf{Z 4 . 2})\end{array}$ \\
\hline \multirow{4}{*}{ Product Quality (X1) } & \multirow{4}{*}{$\begin{array}{l}\text { Fit \& } \\
\text { Finish } \\
\text { (X1.8) }\end{array}$} & \multirow{2}{*}{$\begin{array}{c}\text { Fit \& } \\
\text { Finish } \\
(\mathrm{X} 1.8 .1)\end{array}$} & \begin{tabular}{|l|} 
Pearson \\
Correlation \\
\end{tabular} & $.447^{* * *}$ & $.375^{* *}$ & $.411^{* * *}$ & $.372^{* *}$ & $.358^{* * *}$ & $.375^{* * 2}$ & $.458^{* * *}$ & $.503^{* *}$ & $.464^{* * *}$ & $.401^{* *}$ & $.336^{* *}$ & $.436^{* *}$ \\
\hline & & & \begin{tabular}{|l|} 
Sig. (2- \\
tailed)
\end{tabular} & 0.000 & 0.000 & 0.000 & 0.000 & 0.000 & 0.000 & 0.000 & 0.000 & 0.000 & 0.000 & 0.000 & 0.000 \\
\hline & & \multirow{2}{*}{$\begin{array}{c}\text { Fit \& } \\
\text { Finish } \\
\text { (X1.8.2) }\end{array}$} & \begin{tabular}{|l|} 
Pearson \\
Correlation \\
\end{tabular} & $.505^{* *}$ & $.441^{* *}$ & $.406^{* *}$ & $.465^{* *}$ & $.434^{* *}$ & $.484^{* * *}$ & $.488^{* * *}$ & $.586^{* * *}$ & $.513^{* * *}$ & $.507^{* *}$ & $.404^{* * *}$ & $.433^{* * *}$ \\
\hline & & & $\begin{array}{l}\text { Sig. (2- } \\
\text { tailed) }\end{array}$ & 0.000 & 0.000 & 0.000 & 0.000 & 0.000 & 0.000 & 0.000 & 0.000 & 0.000 & 0.000 & 0.000 & 0.000 \\
\hline
\end{tabular}

Table 10. Pearson Dimension Correlation of Promotional Variables

\begin{tabular}{|c|c|c|c|c|c|c|c|c|c|c|c|c|c|c|c|}
\hline Variable & Dimen & & $\begin{array}{c}\text { Pearson } \\
\text { Correlation }\end{array}$ & $\begin{array}{c}\text { Expectation } \\
\text { (Y1) }\end{array}$ & $\begin{array}{c}\text { Perfor } \\
\text { mance } \\
\text { Outco } \\
\text { mes } \\
\text { (Y2) }\end{array}$ & $\begin{array}{c}\text { Subjective } \\
\text { Disconfor } \\
\text { mation } \\
\text { (Y3) }\end{array}$ & $\begin{array}{c}\text { Repeat } \\
\text { Purchase } \\
\text { (Z1.1) }\end{array}$ & \begin{tabular}{|c|} 
Repeat \\
Purchase \\
(Z1.2)
\end{tabular} & \begin{tabular}{|c|} 
Purchase \\
Across \\
Product and \\
Service Line \\
(Z2.1) \\
\end{tabular} & $\begin{array}{c}\text { Purchase } \\
\text { Across Product } \\
\text { and Service } \\
\text { Line (Z2.2) }\end{array}$ & $\begin{array}{c}\text { Refferal } \\
(\mathbf{Z 3 . 1})\end{array}$ & $\begin{array}{c}\text { Refferal } \\
(\mathbf{Z 3 . 2})\end{array}$ & $\begin{array}{c}\text { Refferal } \\
(\mathbf{Z 3 . 3})\end{array}$ & $\begin{array}{c}\text { Retention } \\
\text { (Z4.1) }\end{array}$ & $\begin{array}{c}\text { Retention } \\
\text { (Z4.2) }\end{array}$ \\
\hline \multirow{4}{*}{ Promotion (X2) } & \multirow{2}{*}{$\begin{array}{c}\text { Sales } \\
\text { Promotion } \\
(\mathrm{X} 2.2) \\
\end{array}$} & \multirow{2}{*}{$\begin{array}{c}\text { Sales } \\
\text { Promotion } \\
(\mathrm{X} 2.2 .1)\end{array}$} & \begin{tabular}{|l|} 
Pearson \\
Correlation
\end{tabular} & $.452^{2=}$ & $.418^{* *}$ & $.420^{* * *}$ & $.356^{* *}$ & $.376^{* * 2}$ & $.334^{* *}$ & $.497^{* *}$ & $.438^{* * *}$ & $.406^{* *}$ & $.360^{* *}$ & $.261^{* *}$ & $.335^{* *}$ \\
\hline & & & Sig. (2-tailed) & 0.000 & 0.000 & 0.000 & 0.000 & 0.000 & 0.000 & 0.000 & 0.000 & 0.000 & 0.000 & 0.000 & 0.000 \\
\hline & \multirow{2}{*}{$\begin{array}{l}\text { Personal Selling } \\
\text { (X2.5) }\end{array}$} & \multirow{2}{*}{$\begin{array}{l}\text { Personal } \\
\text { Selling } \\
\text { (X2.5.1) }\end{array}$} & \begin{tabular}{|l|} 
Pearson \\
Correlation \\
\end{tabular} & $.401^{* *}$ & $.372^{* *}$ & $.371^{* * *}$ & $.410^{* * *}$ & $.445^{* * 5}$ & $.436^{* *}$ & $.490^{* *}$ & $.499^{* * *}$ & $.471^{* *}$ & $.378^{* * *}$ & $.330^{* *}$ & $.388^{* *}$ \\
\hline & & & Sig. (2-tailed) & 0.000 & 0.000 & 0.000 & 0.000 & 0.000 & 0.000 & 0.000 & 0.000 & 0.000 & 0.000 & 0.000 & 0.000 \\
\hline
\end{tabular}

Table 11. Pearson Dimension Correlation of Location Variables

\begin{tabular}{|c|c|c|c|c|c|c|c|c|c|c|c|c|c|c|c|}
\hline Variable & Dime & ension & $\begin{array}{c}\text { Pearson } \\
\text { Correlation }\end{array}$ & $\begin{array}{c}\text { Expectation } \\
\text { (Y1) }\end{array}$ & $\begin{array}{c}\text { Perfor } \\
\text { mance } \\
\text { Outco } \\
\text { mes } \\
\text { (Y2) }\end{array}$ & $\begin{array}{c}\text { Subjective } \\
\text { Disconfor } \\
\text { mation } \\
(\mathrm{Y3})\end{array}$ & $\begin{array}{c}\text { Repeat } \\
\text { Purchase } \\
\text { (Z1.1) }\end{array}$ & $\begin{array}{c}\text { Repeat } \\
\text { Purchase } \\
(\mathrm{Z1} 1.2)\end{array}$ & $\begin{array}{l}\text { Purchase } \\
\text { Across } \\
\text { Product } \\
\text { and } \\
\text { Service }\end{array}$ & $\begin{array}{c}\text { Purchase } \\
\text { Across } \\
\text { Product } \\
\text { and Service } \\
\text { Line (Z2.2) }\end{array}$ & $\begin{array}{c}\text { Refferal } \\
(\mathbf{Z 3 . 1}) \\
\end{array}$ & $\mid \begin{array}{c}\text { Refferal } \\
(\mathbf{Z 3 . 2})\end{array}$ & $\begin{array}{c}\text { Refferal } \\
(\mathbf{Z 3 . 3})\end{array}$ & $\begin{array}{c}\text { Retention } \\
\text { (Z4.1) }\end{array}$ & $\begin{array}{c}\text { Retention } \\
\text { (Z4.2) }\end{array}$ \\
\hline \multirow[t]{2}{*}{ Location (X3) } & \multirow{2}{*}{\begin{tabular}{|c}
$\begin{array}{c}\text { Government } \\
\text { Regulations } \\
\text { (X3.8) }\end{array}$ \\
\end{tabular}} & $\begin{array}{l}\text { Government } \\
\text { Regulations }\end{array}$ & \begin{tabular}{|l|} 
Pearson \\
Correlation
\end{tabular} & $.557^{* *}$ & $.448^{* * *}$ & $.432^{* *}$ & $.409^{* *}$ & $.370^{* * * *}$ & $.413^{* * *}$ & $.434^{* * *}$ & $.467^{* * *}$ & $.410^{* * *}$ & $.389^{* * * *}$ & $.328^{* * *}$ & $.357^{*}$ \\
\hline & & (X3.8.1) & Sig. (2-tailed) & 0.000 & 0.000 & 0.000 & 0.000 & 0.000 & 0.000 & 0.000 & 0.000 & 0.000 & 0.000 & 0.000 & 0.000 \\
\hline
\end{tabular}

Table 12. Pearson Dimensions Correlation Satisfaction Variables

\begin{tabular}{|c|c|c|c|c|c|c|c|c|c|c|c|c|}
\hline Variable & Dime & nsion & $\begin{array}{c}\text { Pearson } \\
\text { Correlation }\end{array}$ & $\begin{array}{c}\text { Expectation } \\
\text { (Y1) }\end{array}$ & \begin{tabular}{|c|} 
Perfor \\
mance \\
Outco \\
mes \\
$($ Y2) \\
\end{tabular} & $\begin{array}{c}\text { Subjective } \\
\text { Disconforma } \\
\text { tion (Y3) }\end{array}$ & $\begin{array}{c}\text { Repeat } \\
\text { Purchase } \\
(\text { Z1.1) }\end{array}$ & $\begin{array}{c}\text { Repeat } \\
\text { Purchase } \\
\text { (Z1.2) }\end{array}$ & \begin{tabular}{|c|} 
Purchase \\
Across \\
Product and \\
Service Line \\
(Z2.1)
\end{tabular} & \begin{tabular}{|c|} 
Purchase \\
Across \\
Product and \\
Service Line \\
(Z2.2) \\
\end{tabular} & $\mid \begin{array}{c}\text { Refferal } \\
(\text { Z3.1 })\end{array}$ & $\begin{array}{c}\text { Refferal } \\
\text { (Z3.2) }\end{array}$ \\
\hline \multirow{6}{*}{ Satisfaction $(Y)$} & \multirow{2}{*}{$\begin{array}{l}\text { Expectation } \\
(\mathrm{Y} 1)\end{array}$} & \multirow{2}{*}{$\begin{array}{c}\text { Expectation } \\
(\mathrm{Y} 1.1)\end{array}$} & \begin{tabular}{|l|} 
Pearson \\
Correlation
\end{tabular} & $.519^{* * *}$ & $.447^{* * *}$ & $.406^{* * *}$ & $.481^{* *}$ & $.463^{* * *}$ & $.420^{* * *}$ & $.411^{* *}$ & $.346^{* *}$ & $.374^{* *}$ \\
\hline & & & Sig. (2-tailed) & 0.000 & 0.000 & 0.000 & 0.000 & 0.000 & 0.000 & 0.000 & 0.000 & 0.000 \\
\hline & \multirow{2}{*}{$\begin{array}{l}\text { Performance } \\
\text { Outcomes } \\
\text { (Y2) }\end{array}$} & \multirow{2}{*}{\begin{tabular}{|c} 
Performance \\
Outcomes \\
(Y2.1)
\end{tabular}} & \begin{tabular}{|l|} 
Pearson \\
Correlation
\end{tabular} & $.490^{* *}$ & $.491^{* * *}$ & $.428^{* * *}$ & $.459^{* *}$ & $.460^{* * *}$ & $.408^{* * *}$ & $.348^{* *}$ & $.290^{* *}$ & $332^{* *}$ \\
\hline & & & \begin{tabular}{|l|} 
Sig. (2-tailed) \\
\end{tabular} & 0.000 & 000 & 0.000 & 0.000 & 0.0 & 0.000 & 0.000 & 0.000 & 0.000 \\
\hline & \multirow{2}{*}{\begin{tabular}{|c|} 
Subjective \\
Disconformat \\
ion (Y3)
\end{tabular}} & \multirow{2}{*}{\begin{tabular}{|c} 
Subjective \\
Disconformat \\
ion (Y3.1)
\end{tabular}} & $\begin{array}{l}\text { Pearson } \\
\text { Correlation }\end{array}$ & $.552^{* *}$ & $.512^{* * *}$ & $.411^{* *}$ & $.521^{* * *}$ & $.457^{* * *}$ & $.397^{* * *}$ & $.344^{* * *}$ & $.220^{* *}$ & $.308^{* *}$ \\
\hline & & & \begin{tabular}{|l|} 
Sig. (2-tailed) \\
\end{tabular} & 0.000 & 0.000 & 0.000 & 0.000 & 0.000 & 0.000 & 0.000 & 0.000 & 0.000 \\
\hline
\end{tabular}

\section{CONCLUSION AND SUGGESTION}

Based on the results of the analysis that has been conducted, the researcher can draw the following conclusions:

1. The product quality with the dimension of fit $\&$ finish has a positive and significant effect on the variable of satisfaction through the dimension of expectation,

2. Product quality with the most dominant dimension of fit $\&$ finish which has a positive and significant effect on the variable of loyalty through the dimension of referral

3. Promotion with the dimension of sales promotion has a positive and significant effect on customer satisfaction through the dimension of expectation,

4. Promotion with the most dominant dimension of personal selling has a positive and significant effect on customer loyalty through the dimension of referral.

5. Location with the more dominant dimension of government regulations has a positive and significant effect on the variable of satisfaction through the dimension of expectation 
6. Location has no significant effect on the variable of loyalty.

7. Customer satisfaction with the most dominant dimension of subjective disconformation has a positive and significant effect on the variable of loyalty through the dimension of repeat purchase.

Here are the managerial suggestions suggested by the author:

1. Lottemart of Taman Surya conducts a random survey of customer satisfaction regularly

2. It would be advisable to conduct a similar study that is looking at the dominant retail marketing mix factors in every Lottemart store in various regions by looking at customer loyalty by using customer satisfaction as a mediating variable for the benchmark, because with the rise of minimarkets that are closer to place where they live, loyalty in the retail world becomes less strong.

Suggestions for academicians and researchers:

1. Further research is recommended that is to conduct a research by looking for other factors outside the model that the author has examined with a figure of $45.1 \%$ in customer satisfaction variance and a figure of $42.4 \%$ in customer loyalty variance.

2. Customer loyalty is an attitude and customer behavior which are inseparable from the environment, culture and socio-economy where a person is located. Therefore, in a multicultural retail business in term of the supply of goods and services, the crosscultural aspect needs to get attention for research.

\section{REFERENCE}

Ayoe, Muyi. (2017). Pengaruh Kualitas Pelayanan Dan Promosi Terhadap Kepuasan Pelanggan Di Rumah Sakit Hermina Serpong Tangerang. Thesis. Jakarta: UMB

Alafityanto (2017). Pengaruh Kualitas Produk, Harga Produk dan Distribusi terhadap Kepuasan Customer serta Pengaruhnya pada Loyalitas Customer (Study pada PT. Berri Indosari). Thesis. Jakarta: UMB

Azisiah, Isanti Chandra (2018). Pengaruh Kualitas Layanan, Harga dan Tempat Terhadap Kepuasan Pasien Puskesmas Taruma Jaya Bekasi. Thesis. Jakarta: UMB

Aryamti, Amelia (2019). “Analisis Kualitas Produk, Kualitas Pelayanan Dan Citra Merek Pada Kepuasan Pelanggan Klinik Kecantikan Dan Pengaruhnya Terhadap Loyalitas Pelanggan". [Online] Available: https://scholar.google.co.id/citations?user=iXADwsAAAAJ\&hl=id\&oi=sra (May 13, 2019)

Ali, Hapzi, Anggita, Rizza (2017). "The Influence of Product Quality, Service Quality and Price to Purchase Decision of SGM Bunda Milk (Study on PT Sarihusada Generasi Mahardika Region Jakarta, South Tangerang District)". Shollars Bulletin. Vol 3, No 6".

Fauzy, Hendra. (2019). Model Kepercayaan Merek: Analisa Perilaku Konsumen Secara Online, Kepuasan Konsumen Terhadap Minat Beli Ulang. Thesis. Jakarta: UMB.

Hadiyana, M. (2017). Pengaruh Kualitas Produk Dan Promosi Terhadap Keputusan Pembelian Dan Dampaknya Pada Loyalitas Konsumen Frestea di Wilayah Bogor Jawa Barat. Thesis. Jakarta: UMB 
Ikhsani, Khilyatin Dyah. (2017). Keputusan Pembelian: Analisis Kualitas Produk, Harga dan Brand Awarness. Thesis. Jakarta: UMB.

Ichlas, Darma. (2017). Pengaruh Promosi, Harga, Dan Kualitas Layanan Terhadap Kepuasan Dan Loyalitas Pelanggan (Studi Kasus Pada CV. 354 Jaya Tehnik Bekasi). Thesis. Jakarta: UMB

Indrawati, Fenny. (2018). "Pengaruh Kualitas Produk Terhadap Loyalitas Pelanggan Dengan Kepuasan Pelanggan Sebagai Variabel Intervening di Cincau Station Surabaya. [Online]Available: http://publication.petra.ac.id/index.php/manajemenbisnis/article/view/7727 (May 13, 2019)

Jogiyanto. (2019). Konsep Dan Aplikasi PLS Untuk Penelitian Enpiris. Penerbit BPFE: Yogyakarta. Edition 17.

Krisdayanto, Iqbal. (2018). "Pengaruh Analisis Pengaruh Harga, Kualitas Pelayanan, Fasilitas, Dan Lokasi Terhadap Kepuasan Konsumen Di I Cafe Lina Putra Net Bandungan ".[Online]Available:

http://jurnal.unpad.ac.id/index.php/MS/articleview/1025 (May 13, 2019)

Khoirulloh. (2018). "Pengaruh Kualitas Pelayanan, Harga Dan Promosi Terhadap Loyalitas Pelanggan Dengan Kepuasan Pembelian Sebagai Variabel Intervening”. [Online]Available: http://jurnal.unpad.ac.id/index.php/MS/article/view/1006 (May 13, 2019)

Kotler, P., Armstrong, G. (2018). Principles of Marketing. Pearson Education Limited: United Kingdom

Kotler, P., Keller. L.K. (2013). Marketing Management. Pearson Education Limited: England. (2009). Manajemen Pemasaran. Erlangga: Jakarta.

Khoironi, Tubagus (2018). "Product Quality, Brand Image and Pricing to Improve Satisfaction Impact on Customer Loyalty". ProQuest Vol 8. pp: 8

Mujianto, (2017). Pengaruh Persepsi Harga, Kualitas Layanan dan Kepercayaan Terhadap Kepuasan Pelanggan Serta Implikasinya Pada Loyalitas Pelanggan. Thesis. Jakarta: UMB.

Paramita, N. (2017). Pengaruh Promosi, Kualitas Layanan, Dan Citra Merek Terhadap Kepuasan Nasabah Serta Implikasinya Terhadap Loyalitas Nasabah Bank BRI Kantor Cabang Kemayoran. Thesis. Jakarta: UMB

Raju, Venkateswara. (2015) "Effectiveness of Promotion Offer Sstrategies and Customer Satisfaction at Bigbazaar”. KIIT Journal of Management. ProQuest. Vol 11 (II).

Rahmadani, Fitri. (2019) "Pengaruh Kualitas Pelayanan, Produk, Harga dan Lokasi Terhadap Loyalitas Pelanggan Dengan Kepuasan Pelanggan Sebagai Variabel Intervening Pada US. Eva Group Mataram". [Online]Available: http://journal.stieamm.ac.id/index.php/valid/article/view/88. (May 17, 2019)

Sugiono. (2008). Metode Penelitian Bisnis. Alvabeta: Bandung (2013). Metode penelitian kuantitatif, kualitatif, dan kombinasi (Mixed methods). CV Alfabeta: Bandung 
Stevan, Julius. (2018). Implikasi Bauran Pemasaran Ritel, Program Loyalitas Kartu Keanggotaan Terhadap Kualitas Pelayanan Dan Loyalitas Pelanggan Hypermart di Kota Tangerang. Thesis. Jakarta: UMB

Sholihin, M., Ratmojo.D. (20183). Analisis SEM-PLS Dengan Warppls 3.0 Untuk Hubungan NonLinier Dalam Penelitian Sosial Dan Bisnis. Andi: Yogyakarta

Sutarti. (2014). “Analisis Pengaruh Harga, Kualitas Pelayanan, Dan Lokasi Terhadap Kepuasan Pelanggan Dengan Keputusan Pembelian Sebagai Variabel Intervening PadaJokerCafé\&Resto”. [Online]Available:http://stiebi.ac.id/jurnal/index.php/Jebi/art icle/view/61. (May 13, 2019)

Tjiptono, F., Chandra, G. (2016). Service, Quality dan Satisfaction. Andi: Yogyakarta.

Wiryani, P. (2019). Waspada! Posisi Supermarket Terancam Minimarket.[Online] Available:http://www.cnbcindonesia.com/market/20190123122749-17-

51974/waspada-posisi-supermarket-terancam-minimarket (May 13, 2019)

Watanabe., Eluiza., Lima., Dario., Torres, Claudio (2013) "Store Image Attributes and Customer Satisfaction in Supermarkets in Campo Grande-MS". Remark-Revista Brasileira de Marketing. ProQuest. Vol 12 pp: 85-107 